\title{
HPV-Related Oropharyngeal Cancer and Biomarkers Based on Epigenetics and Microbiome Profile
}

\section{OPEN ACCESS}

Edited by:

Eleni Anastasiadou,

Sapienza University of Rome, Italy

Reviewed by:

Pankaj Trivedi,

Sapienza University of Rome, Italy Constantinos Marios Mikelis,

Texas Tech University Health Sciences Center, United States

*Correspondence:

Spyridon Gougousis

spygouse@gmail.com

Specialty section: This article was submitted to Signaling,

a section of the journal Frontiers in Cell and Developmental Biology

Received: 02 November 2020 Accepted: 07 December 2020 Published: 14 January 2021

Citation:

Gougousis $S$,

Mouchtaropoulou E, Besli I, Vrochidis P. Skoumpas I and Constantinidis I (2021) HPV-Related Oropharyngeal Cancer and Biomarkers Based on Epigenetics and Microbiome Profile. Front. Cell Dev. Biol. 8:625330. doi: 10.3389/fcell.2020.625330

\author{
Spyridon Gougousis ${ }^{1 *}$, Evangelia Mouchtaropoulou'2, Ioanna Besli', \\ Paraskevas Vrochidis ${ }^{3}$, Ioannis Skoumpas ${ }^{1}$ and loannis Constantinidis ${ }^{4}$ \\ ${ }^{1}$ GH "G. Papanikolaou," ENT, Head and Neck Department, Thessaloniki, Greece, ${ }^{2}$ Center for Research \\ and Technology-Hellas, Institute of Applied Biosciences, Thessaloniki, Greece, ${ }^{3}$ ENT Department, GH Goumenisa, Kilkis, \\ Greece, ${ }^{4}$ 1st Department of Otorhinolaryngology, Aristotle University of Thessaloniki, Thessaloniki, Greece
}

Human papillomavirus (HPV) is considered the main cause of the increasing incidence rates of oropharyngeal squamous cell carcinoma (OPSCC), and soon, the global burden of HPV-related OPSCC is predicted to exceed that of cervical cancer. Moreover, a different molecular profile for HPV-related OPSCC has been described, opening new promising targeted therapies and immunotherapy approaches. Epigenetic and microbiome-based exploration of biomarkers has gained growing interest with a view to the primary oropharyngeal cancer (OPC) screening. Understanding the role of the epigenetic mechanism and the changes that occur during pathogenesis shows appreciable progress in recent years. The different methylation status of DNA and miRNAs demonstrates the value of possible biomarkers discriminating even in different stages of dysplasia. Through whole-genome bisulfite sequencing, differentially methylated regions (DMRs) hold the key to recover missing information. On the other hand, the microbiota investigation signifies a new biomarker approach for the evaluation of OPC. Along with known cofactors playing a major role in microbiota differentiation, HPV-related cases must be explored further for better understanding. The dynamic approach of the shotgun metagenomic sequencing will robustly fill the gap especially in species/strain level and consequently to biomarker detection. The constantly growing incidence of HPV-related OPC should lead us in further investigation and understanding of the unique features of the disease, more accurate diagnostic methods, along with the development and implementation of new, targeted therapies. This paper comprehensively reviews the significance of biomarkers based on epigenetics and microbiome profile in the accuracy of the diagnosis of the HPV-related cancer in the oropharynx.

\section{Keywords: head and neck cancer, HPV, methylation, miRNA, microbiome, biomarkers}

\section{INTRODUCTION}

\section{Epidemiology}

Head and neck squamous cell carcinoma (HNSCC) is the eighth most common cancer worldwide (Stein et al., 2015). Human papillomavirus (HPV)-related oropharyngeal squamous cell carcinoma (HPV-OPSCC) accounts for 25-30\% of all HNSCC total cases (Tanaka and Alawi, 2018). HNSCC displays different characteristics in clinical symptoms, epidemiology, and treatment (surgical and 
pharmaceutical) because of the head and neck anatomical subsites and of the HPV presence in some of these cancers (Pan et al., 2018). HPV-OPSCC patients are usually described as white men, about 60 years old, little tobacco exposure, higher socioeconomic status, increased sexual behavior usually with same-sex contact, and earlier age at sexual debut. Among white people, about 1.8 women and 9.4 men per 100,000 were diagnosed with HPV-associated oropharyngeal cancer (OPC) (Centers for Disease Control and Prevention, 2020b). Predictions of the global percentage of HPV-OPSCC cases are about to transcend cervical cancer soon. HPV was first discovered by Jabłoñska and Gerard Orth in 1978 where they demonstrated that the virus was able to infect basal keratinocytes in the skin or mucosal membranes (Human Papillomaviruses, 2006). In 1983, Syrjänen (2005) was the first to describe the link between HPV infection and HNSCC. Later on, the explicit aspect of HPVrelated cancers in the cervix was confirmed by Harald zur Hausen (Nobel Prize in Medicine 2008) (Pytynia et al., 2014).

However, difficulties in distinguishing the type of cancers arise from the oral cavity and the cancers from the oropharynx. Today, it is well established that HPV infection is a significant risk factor for the development of OPSCC.

Most importantly, HPV is the causal agent, about $70 \%$ (Centers for Disease Control and Prevention, 2020a), in a subset of OPSCCs, and the rising number of HPV-positive OPSCC patients has led to novel considerations regarding the diagnosis and therapeutic management of these patients.

\section{Diagnosis}

HPV detection in OPCs is based on the concomitant assessment of p16 expression by immunohistochemistry (IHC) and the presence of the viral DNA by polymerase chain reaction (PCR)based approaches. Interestingly, the association between p16 expression and HPV positivity does not exist among the nonOPCs. Although the assessment of p16 expression is routinely used along with the diagnosis of HPV infection, the gold standard remains the detection of HPV E6 and E7 messenger RNA (mRNA) expression via quantitative reverse transcription-PCR (qRT-PCR). This is indicative of a transcriptionally active virus within tumor cells (Ndiaye et al., 2014). Different technical methods are used to detect the existence of the HPV, such as in situ hybridization, Southern hybridization, and differential techniques to collect tumor tissues and samples. Hence, a substantial diversity concerning the percentage of HPV-related cancer exists. The use of saliva-based assays has been proposed as a simple and rapid test for detecting HPV-HNSCC, though it remains a subject for validation (Wasserman et al., 2017). For an accurate diagnosis of HPV-OPSCC, the importance of a patient's history and physical examination, along with appropriate imaging, cannot be overemphasized (Lydiatt et al., 2017). In asymptomatic OPSCC patients, an enlarged lateral neck mass may be noticed, which often indicates metastasis to the cervical lymph node. Such occurs commonly in OPSCC due to the relatively late detection of the tumor. As the tumor progresses, symptoms such as dysphasia or tonsillar pain may present. Precancerous lesions may not be easily visualized or palpable during routine ear-nose-throat (ENT) examinations because of the preferred anatomic sites (tonsils, base of the tongue) of HPVOPSCC. Ultimately, only a tissue biopsy provides histopathologic confirmation of the tumor. The HPV status of the tumor can be revealed by PCR or immunohistochemical staining, as previously discussed.

\section{Treatment}

There are now data supporting the assumption that the HPVOPSCC is a clinically distinct subset of HNSCC. HPV-OPSCC is associated with an overall better treatment outcome than nonHPV-OPSCC, with a higher survival rate and lower adverse effects being reported (Ang et al., 2010). In particular, HPVOPSCC has shown a more supportive outcome when treated with radiation, either alone or with concomitant chemotherapy. In the current edition of the American Joint Committee on Cancer (AJCC) manual, HPV-OPSCCs are distinguished from nonHPV-OPSCCs. Clinical (cTNM) and pathologic TNM (pTNM) are used to stage p16-positive, high-risk HPV-OPSCC. cTNM is applied to all patients with p16-positive, high-risk HPVpositive OPSCC, whereas pTNM is used only for patients who undergo surgery for their cancers (Hoffmann and Tribius, 2019). An example of one of the striking changes is reflected in the reclassification of a p16-positive OPSCC cancer $(2 \mathrm{~cm}$ tumor with two positive ipsilateral lymph nodes, T1N2M0) from stage IV in the previous AJCC manual to stage I. Although some challenges exist, including the potential difficulty of identifying the primary tumor site in advanced-stage OPSCC and a lack of case-controlled studies, better prediction of HPV-OPSCC prognosis is expected using both the clinical and the pathologic data sets (Wang et al., 2015). The molecular mechanisms underlying the differences in treatment response between HPVpositive and negative OPSCC remain unclear. A recent study suggests that p16 sensitizes HPV-positive tumor cells to ionizing radiation by inhibiting homologous recombination-mediated DNA repair (Dok et al., 2014). Although, the exact mechanism that increases the survival of HPV-positive OPSCC remains to be more fully elucidated.

Overall, laboratory detection methodologies of HPV-HNSCC patients do not apply same-scale sensitivity to all cases, resulting in misdiagnosis and inability to receive appropriate treatment. New insights will emerge through the discovery of biomarkers with high sensitivity and specificity and with dynamic prospects for tests of each anatomical site. Moreover, non-invasive screening must be further investigated through large-scale studies for early diagnoses, such as the cervix cases (Agorastos et al., 2019).

\section{EPIGENETICS}

\section{DNA Methylation Status of Head and Neck Squamous Cell Carcinoma}

DNA methylation is the epigenetic mechanism that is mainly involved in the physiological control of genome expression. The process by which DNA methylation functions to repress gene transcription from gene promoter regions is altered upon the development of cancer. Factors implicated in changes 
and inducing hypermethylation or hypomethylation pertain to alteration of the activity of DNA methyltransferases (DNMTs), inflammation, and viral infection (Toyota and Yamamoto, 2011). The role of hypermethylation is comprehensible in different types of cancer, whereas hypomethylation, acknowledged as being associated with repeated DNA sequences (Ehrlich, 2009), remains relatively less explored. Findings in a study in B cell chronic lymphocytic leukemia (B-CLL), emerges the interactive role of hypermethylation and hypomethylation status (Kushwaha et al., 2016). When it comes to HPVrelated cancer, hypermethylation has been covered with sizing studies initially focusing on DNA methylation of either the virus or the host.

The hypermethylated promoter of tumor suppressor genes is considered to initiate carcinogenesis and to affect all cellular pathways with a tumor type-specific profile. Therefore, tumor suppressor genes represent the primary choice for biomarker exploration. RASSF1A, TIMP3, and PCQAP/MED15 were presented as a four-panel approach for the earliest possible identification of the incidence of oral cancer (OC)/OPC (Liyanage et al., 2019). Remarkably, the de novo methylation of the promoter $\mathrm{CpG}$ islands of the RASSF1A gene triggers the initiation of OC (Ovchinnikov et al., 2012; Wen et al., 2018). The PITX2 gene, which regulates the cell cycle, has been found to be hypermethylated in HNSCC samples and highly correlated with the HPV positivity. Additionally, oropharynx and oropharyngeal tumors presented higher levels of methylation compared to other tumor sites (Sailer et al., 2017). The IDO1 gene encodes indoleamine 2,3-dioxygenase, whose increased expression has been associated with viral and bacterial infections as well as tumor pathogenesis. In HPV-associated tumors (HNSCC), increased expression of the IDO1 gene was found in conjunction with significantly lower DNA methylation in the promoter flank region. The research results were verified by further investigations of the regulator interferon $\gamma(\operatorname{IFN} \gamma)$ and the expression levels of all genes involved in the pathway [interferon gamma (IFNG), signal tranducer and activator of transcription (STAT)1, STAT2, Janus kinase (JAK)2, and IFN regulator factor (IRF)9] were positively correlated (Sailer et al., 2019). The sal-like 3 protein (SALL3) binds to DNA methyltransferase 3 alpha (DNMT3A), and the silencing of this gene is involved in the regulation of cell growth (Shikauchi et al., 2009). In the case of HNSCC, SALL3 hypermethylation was associated with the expression of two of the three 10-11 translocation family enzymes (TET1, TET2) and DNMT3A methyltransferase, supporting the hypothesis that the SALL3 gene may play a role in the tumorigenesis and may serve as an important biomarker (Misawa et al., 2017). SALL2 is also suggested as a biomarker in the clinical risk assessment, significantly correlated with SALL1 and SALL3 methylation status but not with HPV infection (Imai et al., 2019). Finally, potential prognostic properties of SALL1 indicate the power of discrimination in tumor stages $\mathrm{T} 1$ and T2 in HNSCC (Misawa et al., 2018). Complementary studies show evidence of oral dysplasia and OC of the hypermethylated genes ZNF582, SOX1, and PAX1 (Cheng et al., 2016; Huang et al., 2017; Tang et al., 2019). A well-studied gene, the tumor suppressor EPB41L3, which inhibits cell proliferation and promotes apoptosis, in combination with early and late genes of high-risk HPV subtypes (hrHPV), has arisen as a promising biomarker panel for cervical cancer (Rogeri et al., 2018; Hernández-López et al., 2019; Kelly et al., 2019). For the first time, this panel triaged on OPC cases with evidence of the biomarker utility (Giuliano et al., 2020).

Although aberrant DNA methylation occurs mainly in promoter regions, $\mathrm{CpG}$ island shores and body regions provide valuable information about interactions and methylation profiles (Irizarry et al., 2009). A genome-wide analysis study found that $60 \%$ of differentially methylated genes (DMGs) were hypomethylated, and gene expression was more likely to be affected by hypomethylated DMRs. Namely, the genes NCAN, NRXN1, and COL19A1, involved in the organization of the extracellular matrix, and SYCP2, RPA2, and SMC1B, involved in the structural maintenance of chromosomes during mitosis/meiosis, were found to be hypomethylated and overexpressed in HPV-positive cancers. Moreover, the average methylation levels of significant hyper- (top 25) or hypo- (top 25) DMRs are able to separate HPV-positive from HPV-negative HNSCC specimens for each anatomical site (Esposti et al., 2017). Studies on related scales underline the importance of a novel approach by whole-genome sequencing and how predictive accuracy can vary individually (Ren et al., 2018; Das et al., 2019; Gašperov et al., 2020).

\section{MicroRNA Prospects in Head and Neck Squamous Cell Carcinoma}

Attention has been focused recently on the small non-coding RNA molecules, miRNAs, which are known for RNA interference and posttranscriptional regulation of gene expression. miRNAs target either one gene or simultaneously different genes, thus involved in multiple cell signaling pathways. This epigenetic mechanism of miRNAs is also considered a modulator of histone modifications (Morales et al., 2017) by increasing their target activity when genes with their promoter regions are located in the active chromatin state regions (Tao et al., 2017). Their abnormal expression level is relentlessly studied in recent years, indicating the association in various human cancers (Anastasiadou et al., 2017, 2019; Marco et al., 2018). Some viruses also encode miRNAs (Anastasiadou et al., 2010; Rosato et al., 2012), demonstrating to regulate the host's immune system (Iizasa et al., 2020). On the other hand, the epigenetic regulation of these molecules is covered to a small extent, although indications seem to be significant (Wang et al., 2017).

TP53 tobacco-associated mutations are frequent observations in head and neck tumors. Various miRNA signature associations and the evaluation of the TP53 mutation profile have highlighted their importance for clinical outcome and tumor in tissues (Ganci et al., 2013; Metheetrairut et al., 2019; Chari et al., 2020). Emphasizing the individual miRNAs, miR-145 is a p53regulated gene that acts as a metastasis suppressor by targeting multiple genes in different types of cancer (Sachdeva and Mo, 2010; Leite et al., 2013). This role is also confirmed in laryngeal squamous cell carcinoma (LSCC) by the regulatory axis miR-145-5p/FSCN1 (Gao et al., 2019). Even more, this 
specific miR-145 examined on $\operatorname{HPV}(+)$ and $\mathrm{HPV}(-)$ HNSCC samples shows that $\operatorname{HPV}(+)$ tumor cases have a distinct miRNA profile of the miR-15a/miR-16/, miR-143/miR-145, and the miR106-363 cluster (Lajer et al., 2012). miR-373 belongs to a cluster of four miRNAs located on chromosome 19q13 and has attracted research interest stated as an oncomir in esophageal cancer. The upregulation of the tumor suppressors mir-373 and mir-372 has been associated with proliferation, invasion, and metastasis in oropharyngeal samples, indicating a worse survival overexpression ( $\mathrm{Tu}$ et al., 2015; Zhang et al., 2019). Moreover, a study focusing on miR-373-3p in tumor tissues showed that expression levels may be regulated by the hypomethylated miR373-3p promoter that mediates the developmental process of esophageal squamous cell carcinoma (ESCC) (Wang L. et al., 2019). Contrarily, miR-148a-3p targeting the long non-coding RNA H19 (lncRNA H19) and the DNA methyltransferase enzyme DNMT1 shows to suppress migration and invasion of cancer cells and may have prognostic value in the future (Wu et al., 2016; Wang Y. et al., 2019).

Investigation of individual miRNA molecules may be of use for the benefit of diagnostic and prognostic value in HNSCC, but when it comes to a combination of miRNAs, provides a more significant prediction in clinical outcomes. The diagnostic power of miR-383, miR-615, and miR-877 panel distinguishes patients with HNSCC from healthy donors, with high rates of a receiver operating characteristic (ROC) curve analysis (89.3\% sensitivity and $98.9 \%$ specificity) (Liu et al., 2019). Given the unfavorable prognosis of HPV-negative cancer patients strengthens the need to find biomarkers through miRNA signatures for a more accurate diagnosis (Hess et al., 2019).

\section{MICROBIOME}

The microbiome is one of the developing fields of study and evaluation in recent years not only as a single element in monitoring the normal flora of organisms but also coexistence between host and bacteria. Although great efforts have been made, little is known about the consideration of normal flora due to various factors that affect the microbial community such as age, gender, genetics, mode of birth (normal birth or cesarean section), and nutritional factors (Zapata and Quagliarello, 2015; Dominguez-Bello et al., 2019). Nevertheless, the host-bacteria symbiosis has proven to play an important role in metabolic functions (Chow et al., 2010), and any imbalance could lead to insulin resistance, inflammation, vascular and metabolic disorders (Pascale et al., 2018), and cancer pathogenesis (Chen et al., 2017; Stashenko et al., 2019).

The oral cavity has been characterized by Actinobacteria, Bacteroidetes, Chlamydiae, Chloroflexi, Euryarchaeota, Firmicutes, Fusobacteria, GN02, Proteobacteria, Spirochaetes, SR1, Synergistetes, Tenericutes, and TM7 bacteria taxa at the phylum level, according to the Human Oral Microbiome Database (HOMD). Factors such as smoking, betel quid chewing (Yu et al., 2017), and alcohol consumption (Fan et al., 2018) have been adequately associated with changes of oral flora, giving space for colonization of opportunistic pathogens. Additionally, poor oral hygiene leads to changes in the ratio of bacterial flora, triggering inflammatory oral diseases such as periodontitis and gingivitis (Kilian et al., 2016; Schulz et al., 2019).

Different bacterial profiles in oral squamous cell carcinoma (OSCC) point out that multiple cofactors are playing a crucial role. A comparative study showed that switched microbiota depends on different tissue sites (tumor sites and non-tumor sites). Streptococcus sp. oral taxon 058, Peptostreptococcus stomatis, Streptococcus salivarius, Streptococcus gordonii, Gemella haemolysans, Gemella morbillorum, Johnsonella ignava, and Streptococcus parasanguinis were highly associated with tumor site, whereas Granulicatella adiacens was prevalent at the nontumor site (Pushalkar et al., 2012).

OPC and hypopharyngeal (HP) cancer are distinguishable through a differential microbiome profile. Streptococcus anginosus was only significantly elevated in saliva of OPC patients (Panda et al., 2020). Mutational changes can also variate the relative abundance of bacteria, such as Firmicutes and Bacteroidetes found to be different among groups concerning different mutants (Yang et al., 2018). Considering that HPV promotes carcinogenesis in some cases, studies that included HPV-positive samples in conjunction with oral flora assessment showed different results. A small pilot study found that patients with OC/OPC differed significantly from healthy controls. Interestingly, in the case of HPV-positive samples was demonstrated as a "normal" microbiome profile (Wolf et al., 2017). In contrast, an HPV-positive correlation was found between the genera Haemophilus and Gemella in oral cavity cancer (OCC) and OPC. Additionally, Actinomyces, Parvimonas, Selenomonas, and Prevotella were more abundant in OCC compared to OPC (Lim et al., 2018). On the other hand, a case-control study pointed out that Corynebacterium and Kingella are associated with a decreased risk of OC (Hayes et al., 2018). At species level, it was found that Streptococcus salivarius-Streptococcus vestibularis are abundant in OSCC samples, and more importantly, analysis of subsets of these samples showed that species of the vaginal flora are abundant in saliva (Lactobacillus gasseri/johnsonii and Lactobacillus vaginalis) (Guerrero-Preston et al., 2017).

Associations between the microbial profile and cancer have so far been based mainly on the sequencing of bacterial $16 \mathrm{~S}$ ribosomal RNA (rRNA) genes. It has been shown that significant differences in the analysis of whole bacterial genomes improve the characterization of microbial communities, even at the subtype/strain level (Ranjan et al., 2016; Brumfield et al., 2020).

\section{DISCUSSION}

Molecular biomarkers have become an imperative need for the better, immediate diagnosis and treatment of patients with OPC. The two main areas of research of epigenetics (Table 1) and microbiome profile (Table 2) show excellent prospects. In the case of DNA methylation, several biomarkers have been proposed to differentiate even cancer stages. Regarding microbiome profiles, factors that play a crucial role in changes in flora have been established, and clinical studies have highlighted the 
TABLE 1 | Epigenetic mechanisms related in HNSCC.

\begin{tabular}{|c|c|c|c|c|c|c|}
\hline Author & Tissue & Samples & HPV-related & Hypermethylation & Hypomethylation & Results \\
\hline \multicolumn{7}{|l|}{ DNA methylation } \\
\hline Liyanage et al. (2019) & Saliva & OC/OPC/Controls & Yes & $\begin{array}{l}\text { P16INK4a, RASSF1A, TIMP3, } \\
\text { PCQAP/MED15 }\end{array}$ & - & $\begin{array}{l}\text { Discrimination and early detection of } \\
\text { OC/OPC }\end{array}$ \\
\hline Wen et al. (2018) & $\begin{array}{l}\text { Oral } \\
\text { rinse/Tissue/Blood }\end{array}$ & Oscc/Controls & No & PASSF1A, RARb, CDH1 (meta-analysis) & - & Association with the oral cancer risk \\
\hline Ovchinnikov et al. (2012) & Saliva & HNSCC/Controls & No & RASSF1A, DAPK1, p16INK4a & - & Prediction of incidence risk in HNSCC \\
\hline Sailer et al. (2017) & Tissue & HNSCC/Controls & Yes & PITX2 & - & Prognostic biomarker in HNSCC \\
\hline Sailer et al. (2019) & $\begin{array}{l}\text { Tissue, Cell } \\
\text { lines }\end{array}$ & HNSCC/Controls & Yes & IDO1 & - & $\begin{array}{l}\text { Potential biomarker for prediction of } \\
\text { response to IDO1 immune checkpoint } \\
\text { inhibitors }\end{array}$ \\
\hline Misawa et al. (2017) & Tissue & HNSCC/Controls & Yes & SALL3 & - & Potential biomarker in HNSCC \\
\hline Imai et al. (2019) & Tissue & HNSCC/Controls & Yes & SALL2 & - & Important clinical risk assessment \\
\hline Misawa et al. (2018) & $\begin{array}{l}\text { Tissue, Cell } \\
\text { lines }\end{array}$ & HNSCC/Controls & Yes & TET1,TET2,TET3 & - & $\begin{array}{l}\text { TET3 methylation independently } \\
\text { associated with aggressive tumor }\end{array}$ \\
\hline Cheng et al. (2016) & Oral scrapings & $\begin{array}{l}\text { OPMD/OSCC/ } \\
\text { Controls }\end{array}$ & No & ZNF582, PAX1 & - & $\begin{array}{l}\text { Detection of oral dysplasia and oral } \\
\text { cancer and prediction of oral cancer } \\
\text { recurrence }\end{array}$ \\
\hline Huang et al. (2017) & $\begin{array}{l}\text { Tissue (tumor/ } \\
\text { paracancerous) }\end{array}$ & ESCC/Controls & No & ZNF582, PAX1 & - & $\begin{array}{l}\text { Distinguishing ESCC tumor tissues } \\
\text { from non-tumor tissues }\end{array}$ \\
\hline Tang et al. (2019) & Tissue & ESCC/Controls & No & PAX1, SOX1, ZNF582 & - & $\begin{array}{l}\text { Promising biomarker for ESCC } \\
\text { screening and diagnosis }\end{array}$ \\
\hline Giuliano et al. (2020) & Oral gargles & OPC/Controls & Yes & EPB41L3 & - & Possible utility in identifying OPC early \\
\hline Esposti et al. (2017) & Tissue & HNSCC & Yes & $\begin{array}{l}\text { CDH18, CTNND2 (methylome } \\
\text { analyses) }\end{array}$ & $\begin{array}{l}\text { NCAN, NRXN1, COL19A1, SYCP2, } \\
\text { RPA2, SMC1B (methylome analyses) }\end{array}$ & $\begin{array}{l}\text { Novel epigenetic signature of HPV } \\
\text { infection in HNSCCs independent of } \\
\text { the anatomic site }\end{array}$ \\
\hline Das et al. (2019) & Tissue & $\begin{array}{l}\text { OSCC- } \\
\text { GB/Controls }\end{array}$ & No & TET1 (methylome analyses) & $\begin{array}{l}\text { CD274, CD80, DNMT3B (methylome } \\
\text { analyses) }\end{array}$ & $\begin{array}{l}\text { Indication of novel therapeutic targets, } \\
\text { including immunotherapeutic, for } \\
\text { treatment of OSCC-GB }\end{array}$ \\
\hline Ren et al. (2018) & Tissue & OPSCC/Controls & Yes & $\begin{array}{l}\text { OR6S1, KCNA3,EMBP1, CCDC181, } \\
\text { DPP4,ITGA4,BEND4, } \\
\text { ELMO1,SFMBT2,C1QL3, } \\
\text { MIR129-2,NID2, } \\
\text { HOXB4,ZNF439,ZNF93, } \\
\text { VSTM2B, ZNF137P, ZNF773 } \\
\text { (methylome analyses) }\end{array}$ & - & $\begin{array}{l}20 \text { highly specific DMRs in HPV- related } \\
\text { OPSCC, with potential application to } \\
\text { molecular-based detection tests }\end{array}$ \\
\hline Gašperov et al. (2020) & Tissue & $\begin{array}{l}\text { Oral } \\
\text { lesions/HNSCC/ } \\
\text { Controls }\end{array}$ & Yes & $\begin{array}{l}\text { RAD51B, BARX2, SLC5A10/FAM83G, } \\
\text { NINL NSMCE2, PGAP2, INO80C, IL34, } \\
\text { ZNF516, GFOD2, PARD3, MCEE, } \\
\text { POLM, ASPG,TBC1D2 (Promoters in } \\
\text { HNSCC Tissue Compared to Oral } \\
\text { lesions-methylome analyses) }\end{array}$ & $\begin{array}{l}\text { ART4, EPB41L3, ESRRG, ENPP1, } \\
\text { GNG7, PAPSS2, NGEF, HIPK4, } \\
\text { GPR158, GSG1L, SMPD3, GDF2, } \\
\text { RERE, CDH13, HS3ST4 (Promoters in } \\
\text { HNSCC Tissue Compared to Oral } \\
\text { lesions-methylome analyses) }\end{array}$ & $\begin{array}{l}\text { Potential biomarkers for early } \\
\text { diagnostics of HNSCC and } \\
\text { premalignant oral lesions }\end{array}$ \\
\hline
\end{tabular}


TABLE 1 | Continued

\begin{tabular}{|c|c|c|c|c|c|c|}
\hline Author & Tissue & Samples & HPV-related & miRNA & Methylation status & Results \\
\hline \multicolumn{7}{|l|}{ miRNAs } \\
\hline Gao et al. (2019) & Tissue & $\begin{array}{l}\text { HNSCC/ } \\
\text { LSCC/Controls }\end{array}$ & No & miR-145-5p & Promoter hypermethylation & $\begin{array}{l}\text { miR-145-5p and FSCN1 are } \\
\text { important potential prognostic } \\
\text { markers and therapeutic targets for } \\
\text { LSCC }\end{array}$ \\
\hline Lajer et al. (2012) & Tissue & $\begin{array}{l}\text { HNSCC/TSCC/ } \\
\text { OSCC/PSCC/ } \\
\text { Control }\end{array}$ & Yes & $\begin{array}{l}\text { miR-15a/miR-16/miR195/miR-497 } \\
\text { family, miR-143/miR-145 and the } \\
\text { miR-106-363 cluster }\end{array}$ & - & $\begin{array}{l}\text { New knowledge to known } \\
\text { pathogenic pathways of HPV and } \\
\text { substantiates the oncogenic role of } \\
\text { HPV in subsets of HNSCCs }\end{array}$ \\
\hline Tu et al. (2015) & Tissue/Cell lines & Oscc/Control & No & miR-372, miR-373 & - & $\begin{array}{l}\text { Overexpression of miR-372 and } \\
\text { miR-373 indicates worse survival in } \\
\text { OSCC }\end{array}$ \\
\hline Zhang et al. (2019) & Tissue/Cell lines & OScC/Control & No & miR-373 & - & $\begin{array}{l}\text { MiR-373/SPOP potential } \\
\text { therapeutic target for OSCC }\end{array}$ \\
\hline Wang L. et al. (2019) & Tissue/Cell lines & ESCC/Control & No & $\begin{array}{l}\text { miR-371a-5p, miR- 371b-5p, } \\
\text { miR-372-3p, miR-373-3p }\end{array}$ & $\begin{array}{l}\text { miR-373-3p promoter } \\
\text { hypomethylation }\end{array}$ & $\begin{array}{l}\text { DNA epigenetic modification in the } \\
\text { miR-373-3p promoter region and } \\
\text { the Hippo and p53 signaling } \\
\text { pathways play important roles } \\
\text { during the miR-373-3p mediating } \\
\text { ESCC development process }\end{array}$ \\
\hline Wu et al. (2016) & Tissue & LSCC/Control & No & IncRNA H19/miR-148a-3p/DNMT1 & Promoter hypomethylation & $\begin{array}{l}\text { IncRNA H19 promoted LSCC } \\
\text { progression via miR-148a-3p and } \\
\text { DNMT1 }\end{array}$ \\
\hline Wang Y. et al. (2019) & Tissue/Cell lines & ESCC/Control & No & miR-148a-3p & - & $\begin{array}{l}\text { miR-148a-3p, by targeting DNMT1, } \\
\text { likely regulates cell proliferation and } \\
\text { invasion in esophageal cancer. } \\
\text { Might also be used prognostically in } \\
\text { esophageal cancer and serve as a } \\
\text { therapeutic target in the future }\end{array}$ \\
\hline Liu et al. (2019) & Tissue & HNSCC/Control & Yes & $\begin{array}{l}128 \text { miRNAs as significantly } \\
\text { differentially expressed in HNSCC } \\
\text { tissue compared with the normal } \\
\text { samples }\end{array}$ & - & $\begin{array}{l}\text { hsa-miR-383, hsa-miR-615, and } \\
\text { hsa-miR-877 may serve as an } \\
\text { excellent diagnostic biomarker for } \\
\text { HNSCC, and potential prognostic } \\
\text { significance for HNSCC patients }\end{array}$ \\
\hline Hess et al. (2019) & Tissue & $\begin{array}{l}\text { HNSCC/DKTK- } \\
\text { ROG/LMU-KKG } \\
\text { (radiochemotherapy } \\
\text { received) }\end{array}$ & Yes (negative) & $\begin{array}{l}\text { hsa- let-7g-3p, hsa-miR-6508-5p, } \\
\text { hsa-miR-210-5p, hsa-miR-4306, } \\
\text { and hsa-miR-7161-3p }\end{array}$ & - & $\begin{array}{l}\text { The five-miRNA signature is a } \\
\text { strong and independent prognostic } \\
\text { factor for disease recurrence and } \\
\text { survival of patients with } \\
\text { HPV-negative HNSCC }\end{array}$ \\
\hline
\end{tabular}

DKTK-ROG, German Consortium for Translational Cancer Research-Radiation Oncology Group; ESCC, esophageal squamous cell carcinoma; HNSCC, head and neck squamous cell carcinoma; LMU-KKG, LudwigMaximilians-University of Munich-Clinical Cooperation Group; LSCC, laryngeal squamous cell carcinoma; OC, oral cancer; OPC, oropharyngeal cancer; OPMD, oral potentially malignant disorders; OSCC, oral squamous cell carcinoma; OSCC-GB, Gingivo-buccal oral squamous cell carcinoma; PSCC, pharyngeal squamous cell carcinoma; TSCC, tonsillar squamous cell carcinoma. 
TABLE 2 | Bacteria abundance in HNSCC.

\begin{tabular}{|c|c|c|c|c|c|c|c|c|}
\hline Author & Tissue & Samples & HPV-related & Method & $\begin{array}{l}16 S \text { rRNA } \\
\text { region }\end{array}$ & Bacteria abudance (Tumor) & $\begin{array}{l}\text { Bacteria abudance } \\
\text { (non-tumor) }\end{array}$ & Results \\
\hline \multicolumn{9}{|l|}{ Microbiome profile } \\
\hline $\begin{array}{l}\text { Pushalkar et al. } \\
\text { (2012) }\end{array}$ & Tissue & OSCC/Control & No & $\begin{array}{l}\text { Culture-independent, } \\
\text { cloning, sequencing }\end{array}$ & V4-V5 & $\begin{array}{l}\text { Streptococcus sp. oral taxon } \\
\text { 058, Peptostreptococcus } \\
\text { stomatis, Streptococcus } \\
\text { salivarius, Streptococcus } \\
\text { gordonii, Gemella haemolysans, } \\
\text { Gemella morbillorum, } \\
\text { Johnsonella ignava, and } \\
\text { Streptococcus parasanguinis I }\end{array}$ & Granulicatella adiacens & $\begin{array}{l}\text { Bacterial diversity in the } \\
\text { oral mucosal tissues } \\
\text { from non-tumor and } \\
\text { tumor sites of OSCC } \\
\text { subjects }\end{array}$ \\
\hline Panda et al. (2020) & Saliva & OPC/HPC/Control & & $\begin{array}{l}\text { Next-generation } \\
\text { sequencing }\end{array}$ & V3-V4 & $\begin{array}{l}\text { Haemophilus parainfluenzae, } \\
\text { Haemophilus influenzae and } \\
\text { Prevotella copri and lower } \\
\text { abundance of Rothia } \\
\text { mucilaginosa, Aggregatibacter } \\
\text { segnis, Veillonella dispar, } \\
\text { Prevotella nan- ceiensis, Rothia } \\
\text { aeria, Capnocytophaga } \\
\text { ochracea, Neisseria } \\
\text { bacilliformis, Prevotella } \\
\text { nigrescens, and Selenomonas } \\
\text { noxia in OP and HP cancer } \\
\text { patients./Streptococcus } \\
\text { anginosus in OP cancer }\end{array}$ & - & $\begin{array}{l}\text { Possible non-invasive } \\
\text { diagnostic biomarker } \\
\text { for OP and HP cancer } \\
\text { patients. } \\
\text { Streptococcus } \\
\text { anginosus may be } \\
\text { considered as a } \\
\text { non-invasive diagnostic } \\
\text { biomarker for OP } \\
\text { cancer patients only }\end{array}$ \\
\hline Yang et al. (2018) & Saliva & $\begin{array}{l}\text { OSCC ( } 3 \text { TP53 } \\
\text { mutational } \\
\text { groups)MSC1/2/3 }\end{array}$ & No & $\begin{array}{l}\text { Next-generation } \\
\text { sequencing }\end{array}$ & V4 & $\begin{array}{l}\text { Firmicutes (MSC2), } \\
\text { Bacteroidetes and } \\
\text { Synergistetes ( } \neq \\
\text { MSC2 }<\text { x <MSC3), Seleno- } \\
\text { monas and Rothia ( } \neq \\
\text { MSC1 }<\text { xMSC2 <xMSC3), } \\
\text { Capnocytophaga (MSC3) }\end{array}$ & - & $\begin{array}{l}\text { Oral microbiota is } \\
\text { compositionally and } \\
\text { functionally associated } \\
\text { with the mutational } \\
\text { changes in oral cancer }\end{array}$ \\
\hline Wolf et al. (2017) & Saliva & OCC/OPC/Control & Yes & $\begin{array}{l}\text { Next-generation } \\
\text { sequencing }\end{array}$ & - & $\begin{array}{l}\text { Actinomyces (Actinobacteria), } \\
\text { Schwartzia (Firmicutes), } \\
\text { Treponema (Spirochaetes), and } \\
\text { Selenomonas (Firmicutes) }\end{array}$ & $\begin{array}{l}\text { Bacteroidetes, } \\
\text { Proteobacteria, } \\
\text { Firmicutes }\end{array}$ & $\begin{array}{l}\text { Evidence that } \\
\text { differences in microbial } \\
\text { abundance and } \\
\text { diversity might inform } \\
\text { disease status in SCC } \\
\text { patients }\end{array}$ \\
\hline
\end{tabular}


TABLE 2 | Continued

\begin{tabular}{|c|c|c|c|c|c|c|c|c|}
\hline Author & Tissue & Samples & HPV-related & Method & 16S rRNA region & $\begin{array}{l}\text { Bacteria abudance } \\
\text { (Tumor) }\end{array}$ & $\begin{array}{l}\text { Bacteria abudance } \\
\text { (non-tumor) }\end{array}$ & Results \\
\hline \multicolumn{9}{|c|}{ Microbiome profile } \\
\hline Lim et al. (2018) & Oral rinse & OCC/OPC/Control & Yes & $\begin{array}{l}\text { Next-generation } \\
\text { sequencing }\end{array}$ & V6-V8 & $\begin{array}{l}\text { Rothia, Haemophilus, } \\
\text { Corynebacterium, } \\
\text { Paludibacter, } \\
\text { Porphyromonas, } \\
\text { Oribacterium, and } \\
\text { Capnocytophaga } \\
\text { discriminate OCC and OPC } \\
\text { patients from age-matched } \\
\text { normal healthy } \\
\text { individuals/Haemophilus } \\
\text { and Gemella positive } \\
\text { correlation with HPV } \\
\text { infection }\end{array}$ & - & $\begin{array}{l}\text { Oral microbiome } \\
\text { prediction of the } \\
\text { presence of OCC and } \\
\text { OPC with sensitivity } \\
\text { and specificity of } 100 \\
\text { and } 90 \% \text {, respectively }\end{array}$ \\
\hline $\begin{array}{l}\text { Hayes et al. } \\
\text { (2018) }\end{array}$ & Mouth washes & HNSCC/Control & Yes & Pyrosequencing & V3-V4 & $\begin{array}{l}\text { Corynebacterium (order } \\
\text { Corynebacteriales), Kingella } \\
\text { (order Neisseriales), } \\
\text { Neisseria (order } \\
\text { Neisseriales), Abiotrophia } \\
\text { (order Lactobacillales), } \\
\text { Capnocytophaga (order } \\
\text { Flavobacteriales) and } \\
\text { species Kingella dentificans } \\
\text { and Streptococcus } \\
\text { sanguinis were associated } \\
\text { with reduced risk for larynx } \\
\text { cancer }\end{array}$ & - & $\begin{array}{l}\text { Greater oral abundance } \\
\text { of commensal } \\
\text { Corynebacterium and } \\
\text { Kingella is associated } \\
\text { with decreased risk of } \\
\text { HNSCC }\end{array}$ \\
\hline $\begin{array}{l}\text { Guerrero- } \\
\text { Preston et al. } \\
\text { (2017) }\end{array}$ & Saliva & HNSCC/Control & Yes & $\begin{array}{l}\text { Next-generation } \\
\text { sequencing (454) }\end{array}$ & V3-V5 & $\begin{array}{l}\text { Fusobacterium nucleatum } \\
\text { (600x higher), Lactobacillus } \\
\text { gasseri/johnsonii ( } 710 x \\
\text { higher), Lactobacillus } \\
\text { vaginalis (52x higher), } \\
\text { Streptococcus salivarius: } \\
\text { Streptococcus vestibularis }\end{array}$ & - & $\begin{array}{l}\text { Fusobacterium } \\
\text { nucleatum, } \\
\text { Lactobacillus } \\
\text { gasserijjohnsonii, and } \\
\text { Lactobacillus vaginalis } \\
\text { associated to oral and } \\
\text { oropharyngeal cancer } \\
\text { in saliva from HPV } \\
\text { positive and HPV } \\
\text { negative patients } \\
\text { treated with surgery } \\
\text { and chemoradiation }\end{array}$ \\
\hline
\end{tabular}

HNSCC, head and neck squamous cell carcinoma; HPC, hypopharyngeal cancer; MSC, mutational signature cluster; OCC, oral cavity cancer; OPC, oropharyngeal cancer; OSCC, oral squamous cell carcinoma. 
importance of probiotic groups as therapy in dental diseases (Toiviainen et al., 2014; Alanzi et al., 2018). However, HPVrelated cases are less explored compared to cervical microbiome flora samples. A multifaceted search for biomarkers would allow a better understanding of the molecular mechanisms of carcinogenesis by replacing targeted investigation. Wholegenome bisulfite and shotgun metagenome sequencing, which involves the random sequencing of all genomic content of a microbiome, will contribute to the achievement of this goal in combination with improved bioinformatic analysis. Finally, the synchronous inclusion of the two investigational

\section{REFERENCES}

Agorastos, T., Chatzistamatiou, K., Tsertanidou, A., Mouchtaropoulou, E., Pasentsis, K., Kitsou, A., et al. (2019). Implementation of HPV-based cervical cancer screening combined with self-sampling using a midwifery network across rural greece: the grecoself study. Cancer Prev Res. 12, 701-710. doi: 10.1158/1940-6207.CAPR-19-0192

Alanzi, A., Honkala, S., Honkala, E., Varghese, A., Tolvanen, M., and Söderling, E. (2018). Effect of Lactobacillus rhamnosus and Bifidobacterium lactis on gingival health, dental plaque, and periodontopathogens in adolescents: a randomised placebocontrolled clinical trial. Benef Microbes. 9, 593-602. doi: 10.3920/ BM2017.0139

Anastasiadou, E., Boccellato, F., Vincenti, S., Rosato, P., Bozzoni, I., Frati, L., et al. (2010). Epstein-Barr virus encoded LMP1 downregulates TCL1 oncogene through miR-29b. Oncogene 29, 1316-1328. doi: 10.1038/onc.2009.439

Anastasiadou, E., Jacob, L. S., and Slack, F. J. (2017). Non-coding RNA networks in cancer. Nat. Rev. Cancer. 18, 5-18. doi: 10.1038/nrc.2017.99

Anastasiadou, E., Stroopinsky, D., Alimperti, S., Jiao, A. L., Pyzer, A. R., Cippitelli, C., et al. (2019). Epstein-Barr virus-encoded EBNA2 alters immune checkpoint PD-L1 expression by downregulating miR-34a in B-cell lymphomas. Leukemia 33, 132-147. doi: 10.1038/s41375-018-0178-x

Ang, K. K., Harris, J., Wheeler, R., Weber, R., Rosenthal, D. I., NguyenTân, P. F., et al. (2010). Human papillomavirus and survival of patients with oropharyngeal cancer. N. Engl. J. Med. 363, 24-35. doi: 10.1056/ NEJMoa0912217

Brumfield, K. D., Huq, A., Colwell, R. R., Olds, J. L., and Leddy, M. B. (2020). Microbial resolution of whole genome shotgun and 16S amplicon metagenomic sequencing using publicly available NEON data. PLoS One 15:e0228899. doi: 10.1371/journal.pone.0228899

Centers for Disease Control and Prevention (2020a). HPV-Associated Oropharyngeal Cancer Rates by Race and Ethnicity. Atlanta, GA: Centers for Disease Control and Prevention.

Centers for Disease Control and Prevention (2020b). How Many Cancers are Linked with HPV Each Year?. Atlanta, GA: Centers for Disease Control and Prevention.

Chari, N. S., Ivan, C., Le, X., Li, J., Mijiti, A., Patel, A. A., et al. (2020). Disruption of TP63-miR-27a* feedback loop by mutant TP53 in head and neck cancer. J. Natl. Cancer Inst. 112, 266-277. doi: 10.1093/jnci/djz097

Chen, J., Domingue, J. C., and Sears, C. L. (2017). Microbiota dysbiosis in select human cancers: evidence of association and causality. Semin. Immunol. 32, 25-34. doi: 10.1016/j.smim.2017.08.001

Cheng, S. J., Chang, C. F., Lee, J. J., Chen, H. M., Wang, H. J., Liou, Y., Yen, C., et al. (2016). Hypermethylated ZNF582 and PAX1 are effective biomarkers for detection of oral dysplasia and oral cancer. Oral Oncol. 62, 34-43. doi: 10.1016/j.oraloncology.2016.09.007

Chow, J., Lee, S. M., Shen, Y., Khosravi, A., and Mazmanian, S. K. (2010). Hostbacterial symbiosis in health and disease. Adv. Immunol. 107, 243-274. doi: 10.1016/B978-0-12-381300-8.00008-3

Das, D., Ghosh, S., Maitra, A., Biswas, N. K., Panda, C. K., Roy, B., et al. (2019). Epigenomic dysregulation-mediated alterations of key biological pathways and tumor immune evasion are hallmarks of gingivo-buccal oral cancer. Clin Epigenetics 11:178. doi: 10.1186/s13148-019-0782-2 biomarker fields of interest could promote primary head and neck cancer screening.

\section{AUTHOR CONTRIBUTIONS}

SG and EM wrote the manuscript according to each one's relevant cognitive object. IB, PV, and IS assessed the literature. IC conceived the original idea and supervised the manuscript. All authors contributed to the article and approved the submitted version.

Dok, R., Kalev, P., Van Limbergen, E. J., Asbagh, L. A., Vázquez, I., Hauben, E., et al. (2014). P16INK4a impairs homologous recombination-mediated DNA repair in human papillomavirus-positive head and neck tumors. Cancer Res. 74:1739-1751. doi: 10.1158/0008-5472.CAN-13-2479

Dominguez-Bello, M. G., Godoy-Vitorino, F., Knight, R., and Blaser, M. J. (2019). Role of the microbiome in human development. Gut 68, 1108-1114. doi: 10.1136/gutjnl-2018-317503

Ehrlich, M. (2009). DNA hypomethylation in cancer cells Epigenomics. Epigenomics 1, 239-259. doi: 10.2217/epi.09.33

Esposti, D. D., Sklias, A., Lima, S. C., Beghelli-de la Forest Divonne, S., Cahais, V., Fernandez-Jimenez, N., et al. (2017). Unique DNA methylation signature in HPV-positive head and neck squamous cell carcinomas. Genome Med. 9:33. doi: 10.1186/s13073-017-0419-z

Fan, X., Peters, B. A., Jacobs, E. J., Gapstur, S. M., Purdue, M. P., Freedman, N. D., et al. (2018). Drinking alcohol is associated with variation in the human oral microbiome in a large study of American adults. Microbiome 6:59. doi: 10.1186/s40168-018-0448-x

Ganci, F., Sacconi, A., Bossel Ben-Moshe, N., Manciocco, V., Sperduti, I., Strigari, L., et al. (2013). Expression of TP53 mutation-associated microRNAs predicts clinical outcome in head and neck squamous cell carcinoma patients. Ann. Oncol. 24, 3082-3088. doi: 10.1093/annonc/mdt380

Gao, W., Zhang, C., Li, W., Li, H., Sang, J., Zhao, Q., et al. (2019). Promoter methylation-regulated miR-145-5p Inhibits laryngeal squamous cell carcinoma progression by targeting FSCN1. Mol. Ther. 27, 365-379. doi: 10.1016/j.ymthe. 2018.09.018

Gašperov, M. N., Sabol, I., Božinović, K., Dediol, E., Mravak-Stipetić, M., Licastro, D., et al. (2020). DNA methylome distinguishes head and neck cancer from potentially malignant oral lesions and healthy oral mucosa. Int. J. Mol. Sci. 21:6853. doi: 10.3390/ijms21186853

Giuliano, A. R., Nedjai, B., Lorincz, A. T., Schell, M. J., Rahman, S., Banwait, R., et al. (2020). Methylation of HPV 16 and EPB41L3 in oral gargles: associations with oropharyngeal cancer detection and tumor characteristics. Int. J. Cancer 146, 1018-1030. doi: 10.1002/ijc.32570

Guerrero-Preston, R., White, J. R., Godoy-Vitorino, F., Rodríguez-Hilario, A., Navarro, K., González, H., et al. (2017). High-resolution microbiome profiling uncovers Fusobacterium nucleatum, Lactobacillus gasseri/johnsonii, and Lactobacillus vaginalis associated to oral and oropharyngeal cancer in saliva from HPV positive and HPV negative patients treated with surgery and chemo-radiation. Oncotarget. 8, 110931-110948. doi: 10.18632/oncotarget. 20677

Hayes, R. B., Ahn, J., Fan, X., Peters, B. A., Ma, Y., Yang, L., et al. (2018). Association of oral microbiome with risk for incident head and neck squamous cell cancer. JAMA Oncol. 4, 358-365. doi: 10.1001/jamaoncol.2017.4777

Hernández-López, R., Lorincz, A. T., Torres-Ibarra, L., Reuter, C., ScibiorBentkowska, D., Warman, R., et al. (2019). Methylation estimates the risk of precancer in HPV-infected women with discrepant results between cytology and HPV16/18 genotyping. Clin. Epigenetics 11:140. doi: 10.1186/s13148-0190743-9

Hess, J., Unger, K., Maihoefer, C., Schuttrumpf, L., Wintergerst, L., Heider, T., et al. (2019). A five-microRNA signature predicts survival and disease control of patients with head and neck cancer negative for HPV infection. Clin. Cancer Res. 25, 1505-1516. doi: 10.1158/1078-0432.CCR-18-0776 
Hoffmann, M., and Tribius, S. (2019). HPV and oropharyngeal cancer in the eighth edition of the TNM classification: pitfalls in practice. Transl. Oncol. 12, 1108-1112. doi: 10.1016/j.tranon.2019.05.009

Huang, J., Wang, G., Tang, J., Zhuang, W., Wang, L. P., Liou, Y. L., et al. (2017). DNA methylation status of PAX1 and ZNF582 in esophageal squamous cell carcinoma. Int. J. Environ. Res. Public Health 14:216. doi: 10.3390/ ijerph 14020216

Human Papillomaviruses (2006). IARC Official: Free Download, Borrow, and Streaming: Internet Archive, Vol. 90. Geneva: World Health Organization.

Iizasa, H., Kim, H., Kartika, A. V., Kanehiro, Y., and Yoshiyama, H. (2020). Role of viral and host microRNAs in immune regulation of epstein-barr virus-associated diseases. Front. Immunol. 11:367. doi: 10.3389/fimmu.2020. 00367

Imai, A., Mochizuki, D., Misawa, Y., Nakagawa, T., Endo, S., Mima, M., et al. (2019). SALL2 is a novel prognostic methylation marker in patients with oral squamous carcinomas: associations with SALL1 and SALL3 methylation status. DNA Cell Biol. 38, 678-687. doi: 10.1089/dna.2018.4597

Irizarry, R. A., Ladd-Acosta, C., Wen, B., Wu, Z., Montano, C., Onyango, P., et al. (2009). Genome-wide methylation analysis of human colon cancer reveals similar hypo-and hypermethylation at conserved tissue-specific CpG island shores. Nat. Genet. 41, 178-186. doi: 10.1038/ng.298

Kelly, H., Benavente, Y., Pavon, M. A., De Sanjose, S., Mayaud, P., and Lorincz, A. T. (2019). Performance of DNA methylation assays for detection of highgrade cervical intraepithelial neoplasia (CIN2+): a systematic review and meta-analysis. Br. J. Cancer 121, 954-965. doi: 10.1038/s41416-019-0593-4

Kilian, M., Chapple, I. L. C., Hannig, M., Marsh, P. D., Meuric, V., Pedersen, A. M. L., et al. (2016). The oral microbiome - An update for oral healthcare professionals. Br. Dent. J. 221, 657-666. doi: 10.1038/sj.bdj.2016.865

Kushwaha, G., Dozmorov, M., Wren, J. D., Qiu, J., Shi, H., and Xu, D. (2016). Hypomethylation coordinates antagonistically with hypermethylation in cancer development: a case study of leukemia. Hum. Genomics 10:18. doi: 10.1186/ s40246-016-0071-5

Lajer, C. B., Garnćs, E., Friis-Hansen, L., Norrild, B., Therkildsen, M. H., Glud, M., et al. (2012). The role of miRNAs in human papilloma virus (HPV)-associated cancers: bridging between HPV-related head and neck cancer and cervical cancer. Br. J. Cancer 106, 1526-1534. doi: 10.1038/bjc.2012.109

Leite, K. R. M., Tomiyama, A., Reis, S. T., Sousa-Canavez, J. M., Sañudo, A., Camara-Lopes, L. H., et al. (2013). MicroRNA expression profiles in the progression of prostate cancer-from high-grade prostate intraepithelial neoplasia to metastasis. Urol. Oncol. Semin. Orig. Investig. 31, 796-801. doi: 10.1016/j.urolonc.2011.07.002

Lim, Y., Fukuma, N., Totsika, M., Kenny, L., Morrison, M., and Punyadeera, C. (2018). The performance of an oral microbiome biomarker panel in predicting oral cavity and oropharyngeal cancers. Front. Cell Infect. Microbiol. 8:267. doi: $10.3389 /$ fcimb.2018.00267

Liu, C., Yu, Z., Huang, S., Zhao, Q., Sun, Z., Fletcher, C., et al. (2019). Combined identification of three miRNAs in serum as effective diagnostic biomarkers for HNSCC. EBioMedicine 50, 135-143. doi: 10.1016/j.ebiom.2019.11.016

Liyanage, C., Wathupola, A., Muraleetharan, S., Perera, K., Punyadeera, C., and Udagama, P. (2019). Promoter hypermethylation of tumor-suppressor genes p16INK4a, RASSF1A, TIMP3, and PCQAP/MED15 in salivary DNA as a quadruple biomarker panel for early detection of oral and oropharyngeal cancers. Biomolecules 9:148. doi: 10.3390/biom 9040148

Lydiatt, W. M., Patel, S. G., O'Sullivan, B., Brandwein, M. S., Ridge, J. A., Migliacci, J. C., et al. (2017). Head and neck cancers-major changes in the American Joint Committee on cancer eighth edition cancer staging manual. CA Cancer J. Clin. 67, 122-137. doi: 10.3322/caac.21389

Marco, M., Ramassone, A., Pagotto, S., Anastasiadou, E., Veronese, A., and Visone, R. (2018). MicroRNAs in autoimmunity and hematological malignancies. Int. J. Mol. Sci. 19:3139. doi: 10.3390/ijms19103139

Metheetrairut, C., Chotigavanich, C., Amornpichetkul, K., Keskool, P., Ongard, S., and Metheetrairut, C. (2019). Expression levels of miR-34-family microRNAs are associated with TP53 mutation status in head and neck squamous cell carcinoma. Eur. Arch. Otorhinolaryngol. 276, 521-533. doi: 10.1007/s00405018-5223-x

Misawa, K., Imai, A., Mochizuki, D., Mima, M., Endo, S., Misawa, Y., et al. (2018). Association of TET3 epigenetic inactivation with head and neck cancer. Oncotarget 9, 24480-24493. doi: 10.18632/oncotarget.25333
Misawa, K., Mochizuki, D., Imai, A., Misawa, Y., Endo, S., Mima, M., et al. (2017) Epigenetic silencing of SALL3 is an independent predictor of poor survival in head and neck cancer. Clin. Epigenetics. 9:64. doi: 10.1186/s13148-017-0363-1

Morales, S., Monzo, M., and Navarro, A. (2017). Epigenetic regulation mechanisms of microRNA expression. Biomol. Concepts 8, 203-212. doi: 10.1515/bmc2017-0024

Ndiaye, C., Mena, M., Alemany, L., Arbyn, M., Castellsagué, X., Laporte, L., et al. (2014). HPV DNA, E6/E7 mRNA, and p16INK4a detection in head and neck cancers: a systematic review and meta-analysis. Lancet Oncol. 15, 1319-1331. doi: 10.1016/S1470-2045(14)70471-1

Ovchinnikov, D. A., Cooper, M. A., Pandit, P., Coman, W. B., Cooper-White, J. J., Keith, P., et al. (2012). Tumor-suppressor gene promoter hypermethylation in saliva of head and neck cancer patients. Transl. Oncol. 5, 321-326. doi: $10.1593 /$ tlo. 12232

Pan, C., Issaeva, N., and Yarbrough, W. G. (2018). HPV-driven oropharyngeal cancer: current knowledge of molecular biology and mechanisms of carcinogenesis. Cancers Head Neck 3:12. doi: 10.1186/s41199-018-0039-3

Panda, M., Rai, A. K., Rahman, T., Das, A., Das, R., Sarma, A., et al. (2020). Alterations of salivary microbial community associated with oropharyngeal and hypopharyngeal squamous cell carcinoma patients. Arch. Microbiol. 202, 785-805. doi: 10.1007/s00203-019-01790- 1

Pascale, A., Marchesi, N., Marelli, C., Coppola, A., Luzi, L., Govoni, S., et al. (2018). Microbiota and metabolic diseases. Endocrine 61, 357-371. doi: 10 1007/s12020-018-1605-5

Pushalkar, S., Ji, X., Li, Y., Estilo, C., Yegnanarayana, R., Singh, B., et al. (2012). Comparison of oral microbiota in tumor and non-tumor tissues of patients with oral squamous cell carcinoma. BMC Microbiol. 12:144. doi: 10.1186/1471-218012-144

Pytynia, K. B., Dahlstrom, K. R., and Sturgis, E. M. (2014). Epidemiology of HPV-associated oropharyngeal cancer. Oral Oncol. 50, 380-386. doi: 10.1016/ j.oraloncology.2013.12.019

Ranjan, R., Rani, A., Metwally, A., McGee, H. S., and Perkins, D. L. (2016). Analysis of the microbiome: advantages of whole genome shotgun versus $16 \mathrm{~S}$ amplicon sequencing. Biochem. Biophys. Res. Commun. 469, 967-977. doi: 10.1016/j.bbrc. 2015.12.083

Ren, S., Gaykalova, D., Wang, J., Guo, T., Danilova, L., Favorov, A., et al. (2018). Discovery and development of differentially methylated regions in human papillomavirus-related oropharyngeal squamous cell carcinoma. Int. J. Cancer 143, 2425-2436. doi: 10.1002/ijc.31778

Rogeri, C. D., Silveira, H. C. S., Causin, R. L., Villa, L. L., Stein, M. D., de Carvalho, A. C., et al. (2018). Methylation of the hsa-miR-124, SOX1, TERT, and LMX1A genes as biomarkers for precursor lesions in cervical cancer. Gynecol. Oncol. 150, 545-551. doi: 10.1016/j.ygyno.2018.06.014

Rosato, P., Anastasiadou, E., Garg, N., Lenze, D., Boccellato, F., Vincenti, S., et al. (2012). Differential regulation of miR-21 and miR-146a by epsteinbarr virus-encoded EBNA2. Leukemia 26, 2343-2352. doi: 10.1038/leu. 2012.108

Sachdeva, M., and Mo, Y. Y. (2010). MicroRNA-145 suppresses cell invasion and metastasis by directly targeting mucin 1 . Cancer Res. 70, 378-387. doi: 10.1158/ 0008-5472.CAN-09-2021

Sailer, V., Gevensleben, H., Dietrich, J., Goltz, D., Kristiansen, G., Bootz, F., et al. (2017). Clinical performance validation of PITX2 DNA methylation as prognostic biomarker in patients with head and neck squamous cell carcinoma. PLoS One 12:e0179412. doi: 10.1371/journal.pone.0179412

Sailer, V., Sailer, U., Bawden, E. G., Zarbl, R., Wiek, C., Vogt, T. J., et al. (2019). DNA methylation of indoleamine 2,3-dioxygenase 1 (IDO1) in head and neck squamous cell carcinomas correlates with IDO1 expression, HPV status, patients' survival, immune cell infiltrates, mutational load, and interferon $\gamma$ signature. EBioMedicine 48, 341-352. doi: 10.1016/j.ebiom.2019. 09.038

Schulz, S., Porsch, M., Grosse, I., Hoffmann, K., Schaller, H. G., and Reichert, S. (2019). Comparison of the oral microbiome of patients with generalized aggressive periodontitis and periodontitis-free subjects. Arch. Oral Biol. 99, 169-176. doi: 10.1016/j.archoralbio.2019.01.015

Shikauchi, Y., Saiura, A., Kubo, T., Niwa, Y., Yamamoto, J., Murase, Y., et al. (2009). SALL3 interacts with DNMT3A and shows the ability to inhibit CpG island methylation in hepatocellular carcinoma. Mol. Cell. Biol. 29, 1944-1958. doi: 10.1128/MCB.00840-08 
Stashenko, P., Yost, S., Choi, Y., Danciu, T., Chen, T., Yoganathan, S., et al. (2019). The oral mouse microbiome promotes tumorigenesis in oral squamous cell carcinoma. mSystems 4, 323-342. doi: 10.1128/mSystems.00323-19

Stein, A. P., Saha, S., Kraninger, J. L., Swick, A. D., Yu, M., Lambert, P. F., et al. (2015). Prevalence of human papillomavirus in oropharyngeal cancer. Cancer J. 21, 138-146. doi: 10.1097/PPO.0000000000000115

Syrjänen, S. (2005). Human papillomavirus (HPV) in head and neck cancer. J. Clin. Virol. 32, 59-66. doi: 10.1016/j.jcv.2004.11.017

Tanaka, T. I., and Alawi, F. (2018). Human papillomavirus and oropharyngeal cancer. Dent. Clin. North Am. 62, 111-120. doi: 10.1016/j.cden.2017.08.008

Tang, L., Liou, Y. L., Wan, Z. R., Tang, J., Zhou, Y., Zhuang, W., et al. (2019). Aberrant DNA methylation of PAX1, SOX1 and ZNF582 genes as potential biomarkers for esophageal squamous cell carcinoma. Biomed. Pharmacother. 120:109488. doi: 10.1016/j.biopha.2019.109488

Tao, B. B., Liu, X. Q., Zhang, W., Li, S., Dong, D., Xiao, M., et al. (2017). Evidence for the association of chromatin and microRNA regulation in the human genome. Oncotarget 8, 70958-70966. doi: 10.18632/oncotarget.20214

Toiviainen, A., Jalasvuori, H., Lahti, E., Gursoy, U., Salminen, S., Fontana, M., et al. (2014). Impact of orally administered lozenges with Lactobacillus rhamnosus GG and Bifidobacterium animalis subsp. lactis BB-12 on the number of salivary mutans streptococci, amount of plaque, gingival inflammation and the oral microbiome in healthy adults. Clin. Oral Investig. 19, 77-83. doi: 10.1007/ s00784-014-1221-6

Toyota, M., and Yamamoto, E. (2011). DNA methylation changes in cancer. Prog. Mol. Biol. Transl. Sci. 101, 447-457. doi: 10.1016/B978-0-12-387685-0.00014-7

Tu, H. F., Chang, K. W., Cheng, H. W., and Liu, C. J. (2015). Upregulation of miR372 and -373 associates with lymph node metastasis and poor prognosis of oral carcinomas. Laryngoscope 125, E365-E370. doi: 10.1002/lary.25464

Wang, L., Wang, L., Chang, W., Li, Y., and Wang, L. (2019). MicroRNA373 promotes the development of esophageal squamous cell carcinoma by targeting LATS2 and OXR1. Int. J. Biol. Markers 34, 148-155. doi: 10.1177/ 1724600819827964

Wang, M. B., Liu, I. Y., Gornbein, J. A., and Nguyen, C. T. (2015). HPV-positive oropharyngeal carcinoma: a systematic review of treatment and prognosis. Otolaryngol. Head Neck Surg. 153, 758-769. doi: 10.1177/0194599815592157

Wang, S., Wu, W., and Claret, F. X. (2017). Mutual regulation of microRNAs and DNA methylation in human cancers. Epigenetics 12, 187-197.

Wang, Y., Hu, Y., Guo, J., and Wang, L. (2019). miR-148a-3p suppresses the proliferation and invasion of esophageal cancer by targeting DNMT1. Genet. Test Mol. Biomarkers 23, 98-104.
Wasserman, J. K., Rourke, R., Purgina, B., Caulley, L., Dimitroulakis, J., Corsten, M., et al. (2017). HPV DNA in saliva from patients with SCC of the head and neck is specific for p16-positive oropharyngeal tumours. J. Otolaryngol. Head Neck Surg. 46:3.

Wen, G., Wang, H., and Zhong, Z. (2018). Associations of RASSF1A, RAR $\beta$, and $\mathrm{CDH} 1$ promoter hypermethylation with oral cancer risk. Medicine 97:e9971.

Wolf, A., Moissl-Eichinger, C., Perras, A., Koskinen, K., Tomazic, P. V., and Thurnher, D. (2017). The salivary microbiome as an indicator of carcinogenesis in patients with oropharyngeal squamous cell carcinoma: a pilot study. Sci Rep. 7:5867.

Wu, T., Qu, L., He, G., Tian, L., Li, L., Zhou, H., et al. (2016). Regulation of laryngeal squamous cell cancer progression by the lncRNA H19/miR148a-3p/DNMT1 axis. Oncotarget 7, 11553-11566. doi: 10.18632/oncotarget. 7270

Yang, S. F., Da Huang, H., Fan, W. L., Jong, Y. J., Chen, M. K., Huang, C. N., et al. (2018). Compositional and functional variations of oral microbiota associated with the mutational changes in oral cancer. Oral Oncol. 77, 1-8. doi: 10.1016/j. oraloncology.2017.12.005

Yu, G., Phillips, S., Gail, M. H., Goedert, J. J., Humphrys, M. S., Ravel, J., et al. (2017). The effect of cigarette smoking on the oral and nasal microbiota. Microbiome 5:3. doi: 10.1186/s40168-016-0226-6

Zapata, H. J., and Quagliarello, V. J. (2015). The microbiota and microbiome in aging: potential implications in health and age-related diseases. J. Am. Geriatr. Soc. 63, 776-781. doi: 10.1111/jgs.13310

Zhang, X. J., Jin, Y., Song, J. L., and Deng, F. (2019). MiR-373 promotes proliferation and metastasis of oral squamous cell carcinoma by targeting SPOP. Eur. Rev. Med. Pharmacol. Sci. 23, 5270-5276.

Conflict of Interest: The authors declare that the research was conducted in the absence of any commercial or financial relationships that could be construed as a potential conflict of interest.

Copyright (C) 2021 Gougousis, Mouchtaropoulou, Besli, Vrochidis, Skoumpas and Constantinidis. This is an open-access article distributed under the terms of the Creative Commons Attribution License (CC BY). The use, distribution or reproduction in other forums is permitted, provided the original author $(s)$ and the copyright owner(s) are credited and that the original publication in this journal is cited, in accordance with accepted academic practice. No use, distribution or reproduction is permitted which does not comply with these terms. 